\title{
A 15 tételes Rövid Geriátriai Depresszió Skála hazai alkalmazásával szerzett tapasztalatok normatív mintán
}

\author{
SZEKERES TAMÁS ${ }^{1 *}$ - HARGITAI RITA² \\ ${ }^{1}$ Semmelweis Egyetem, Általános Orvostudományi Kar, Klinikai Pszichológia Tanszék, \\ Budapest, Magyarország \\ ${ }^{2}$ Pázmány Péter Katolikus Egyetem, Pszichológiai Intézet, Személyiség- és Klinikai \\ Pszichológia Tanszék, Budapest, Magyarország
}

(Beérkezett: 2020. július 25.; elfogadva: 2021. május 15.)

Bevezetés: Az időskori depresszió gyakran aluldiagnosztizált, noha a vezető pszichés problémát jelenti ebben az életkorban. A Rövid Geriátriai Depresszió Skála (GDS-SF) az időskori depresszió tüneteinek felmérésére alkalmas kérdőív, amelyet gyakran alkalmaznak nemzetközi viszonylatban a klinikumban. Célkitüzés: Jelen tanulmány célkitúzése kettős. Elsődleges célja a 15 tételes Rövid Geriátriai Depresszió Skála (GDS-SF) hazai normatív mintán történő tesztelése és az alkalmazásával szerzett tapasztalatok közreadása. Másodsorban arra a kérdésre keressük a választ, hogy az idősek mintáján van-e protektív szerepe az online tér használatának a depresszió vonatkozásában. Módszerek: A keresztmetszeti, kérdőíves kutatásban 65 éves és afeletti életkorú vizsgálati személyek önkéntesen vettek részt, az adatokat anonim módon, papír-ceruza alapon $(n=142)$ és online $(n=167)$ formában gyújtöttük. A kérdőív validálásához az Egészségügyi Világszervezet Rövidített Életminőség Kérdőívét, a Rövidített WHO Jól-Lét Kérdőívet, valamint a Zung Önértékelő Depresszió Skálát használtuk. A válaszmeghamisító tendenciák szúrésére a Caprara-féle Big Five Kérdőív Szociális Kívánatosság alskáláját alkalmaztuk. Eredmények: A parallelelemzés eredménye egyfaktoros struktúrát jelez, és az egyetlen faktor az összvariancia $64,8 \%$-át magyarázza. A kérdőív megbízhatósága kiváló (Cronbach- $\alpha=0,95)$. A GDS-SF az elvárásoknak megfelelő irányú és mértékú korrelációt mutatott a validáláshoz alkalmazott mérőeszközökkel: a GDS-SF és az életminőség alfaktorai közötti korrelációs együttható $(r)$ értéke $-0,59$ és $-0,61$ közötti $(p<0,001)$, a jólléttel $-0,71(p<0,001)$, míg a Zung Önértékelő Depresszió Skálával 0,74 $(p<0,001)$. A papíralapú és az online adatgyújtésben részt vevő vizsgálati személyek körében nem találtunk szignifikáns különbséget a depreszszió előfordulási gyakoriságában, amennyiben kontroll alatt tartjuk az életkor és az iskolai végzettség hatását. Következtetések: A 15 tételes Rövid Geriátriai Depresszió Skála magyar verziója megbízható és érvényes eszköz az időskori depresszió mérésére normatív mintán, miközben a klinikai minta vonatkozásában további vizsgálatok szükségesek.

Kulcsszavak: időskori depresszió, 15 tételes Rövid Geriátriai Depresszió Skála, pszichometriai jellemzők, online adatgyújtés

\footnotetext{
* Levelező szerző: Szekeres Tamás, Semmelweis Egyetem, Általános Orvostudományi Kar, Klinikai Pszichológia Tanszék, 1085 Budapest, Üllői út 25. E-mail: szekeres.tamas2@med. semmelweis-univ.hu
} 


\section{Az időskori depresszió mérése}

Az idősödés az élet természetes folyamata (McGuire, Ford, \& Umed, 2006), a demográfiai öregedés meghatározó társadalmi jelenség világszerte (WHO, 2008). Magyarországon a 65 éves és ennél idősebb népesség aránya 1990 és 2017 között 13\%-ról 19\%-ra növekedett. Az Egészségügyi Világszervezet előrejelzése alapján Európában az idősebb korosztály (65 év felettiek) aránya 2070-re eléri a 29\%-ot (European Commission, 2017). Egészségi állapotukat tekintve a 65 év felettiek 18\%-a rossznak, 10\%-a pedig nagyon rossznak ítéli meg saját egészségi állapotát (Monostori \& Gresits, 2018). Az életkor előrehaladtával nem csupán a szomatikus megbetegedések aránya nő, hanem a pszichiátriai betegségek - kiváltképp a depresszió - előfordulása is egyre gyakoribb.

Magyarországon a depresszió által érintett népesség aránya az összpopuláció vonatkozásában 9\% körüli (Kovács \& Tóth, 2015). A depresszív tünetegyüttes gyakorisága azonban az életkor előrehaladásával nő, így a 65 év feletti átlagpopulációban 15\% körülire becsülik az arányát (Gallo \& Bogner, 2003). Nemzetközi áttekintés alapján a középsúlyos depresszió előfordulási gyakorisága 4-13\%, míg a súlyos depresszió prevalenciája 1-4\% közötti idősek körében (Alexopoulos, 2005). A 74 évesnél idősebb populációban ez az arány magasabb, átlagos elófordulása 25\%-os: 16,4\% az enyhe, $7,5 \%$ a közepesen súlyos és 1,1\% a súlyos depresszió prevalenciája (Forlani és mtsai, 2014). Noha az időskori depresszió tekintetében egyre több tanulmány kerül publikálásra, még mindig kevés empirikus vizsgálatot végeznek. Magyarországon Kovács, Kopp és Rózsa (2003), valamint az Országos Orvosi Rehabilitációs Intézet Baleseti Mozgássérültek Rehabilitációs Osztályának munkatársai végeztek felméréseket az időskori depresszió vonatkozásában (Mészáros \& Szikriszt, 2013). Ezen adatok alapján is kitúnik az időskori depresszió jelentősége, hiszen a 60 év feletti személyek kb. 40\%-ánál fordulnak eló enyhe, 5-20\%-ánál pedig súlyos depresszív tünetek. A hazai gyakorlatban a szürővizsgálat leginkább kérdőíves formában történik (Ajtay, Petruska, \& Hegyi, 2008; Beck, 1961; Bouvard, Charles, \& Guerin, 1992). Gyakran a szomatikus panaszok állnak a tüneti kép előterében, ezért kiemelten fontos a szomatikus betegségek tüneteitől való elkülönítés (Osváth, 2013) és az időskori depresszió differenciáldiagnosztikája (Gonda, Molnár, Torzsa, \& Rihmer, 2009).

Bár egyre nő a nemzetközi érdeklődés az időskori mentális egészség szerepe iránt, az eltérő mérőeszközök nemzetközi összehasonlításra, valamint a depresszió előfordulási gyakoriságának tényleges felmérésére csak korlátozottan alkalmasak (Kósa \& Bíró, 2018). A depresszió kérdőívvel való szúrésére a hazai gyakorlatban a Beck Depresszió Kérdőívet alkalmazzák a leg- 
gyakrabban (Ajtay, Petruska, Hegyi, \& Perczel-Forintos, 2008), ugyanakkor a depresszió időskori populációban történő szúrővizsgálatára angolszász területen a Royal College of General Practitioners és a British Geriatrics Society a Yesavage és munkatársai (1983) által kidolgozott Geriatric Depression Scale-t (Geriátriai Depresszió Skála; GDS) ajánlja. E kérdőív egyik nagy előnye, hogy kifejezetten idős populációra dolgozták ki, másik pozitívuma, hogy nem tartalmaz szomatikus tünetekre vonatkozó tételeket, amelyek az életkor előrehaladtát vagy a romló fizikai állapotot kísérik. Ilyen például a csökkent étvágy, az alvási nehézségek vagy az alacsonyabb energiaszint, amelyek nemcsak a depressziót, hanem számos krónikus fizikai egészségi problémát is jellemezhetnek (Lichtenberg, 2010). Harmadrészt, az igen-nem típusú válaszformátuma könnyen kitölthetó az idősek által. Ezért az angol nyelvú Geriátriai Depresszió Skála nemzetközi viszonylatban az egyik leggyakrabban alkalmazott kérdőív az időskori depresszió szúrésére, amelyet közel 40 nyelvre adaptáltak már. ${ }^{1}$ Az elmúlt évtizedekben az eredeti 30 tételes kérdő́ivnek elkészült a 15 tételes rövid verziója is (Geriatric Depression Scale Short Form; GDS-SF; Sheikh \& Yesavage, 1986). A kérdőív 10 egyenes és 5 fordított tételből áll. A rövid önkitöltős kérdőíven a vizsgált személyek kényszerválasztás (igen-nem) formájában rögzíthetik válaszukat az egyes tételekkel kapcsolatban, aszerint, hogy az elmúlt két hét során hogyan érezték magukat. A kérdések a napi életmódra, illetve az érzésekre vonatkoznak. A skála belső konzisztenciája magasnak bizonyult nemcsak az angol nyelvú, de a különböző nyelvi adaptációk során is (Kim, DeCoster, Huang, \& Bryant, 2013). Továbbá a Zung Önértékelő Depresszió Skálával történő validálás alapján a GDS-SF (Geriatric Depression Scale Short Form) hatékonyan különítette el a vizsgálati csoportokat a depressziós tüneteik alapján (Sheikh \& Yesavage, 1986).

A GDS-SF skála faktorelemzésére irányuló nemzetközi kutatási eredmények azonban igen változatosak (lásd 1. táblázat), így nehéz eldönteni, hogy a konstruktum pontosan hány dimenzióval jellemezhetó.

1 https://web.stanford.edu/ yesavage/GDS.html 


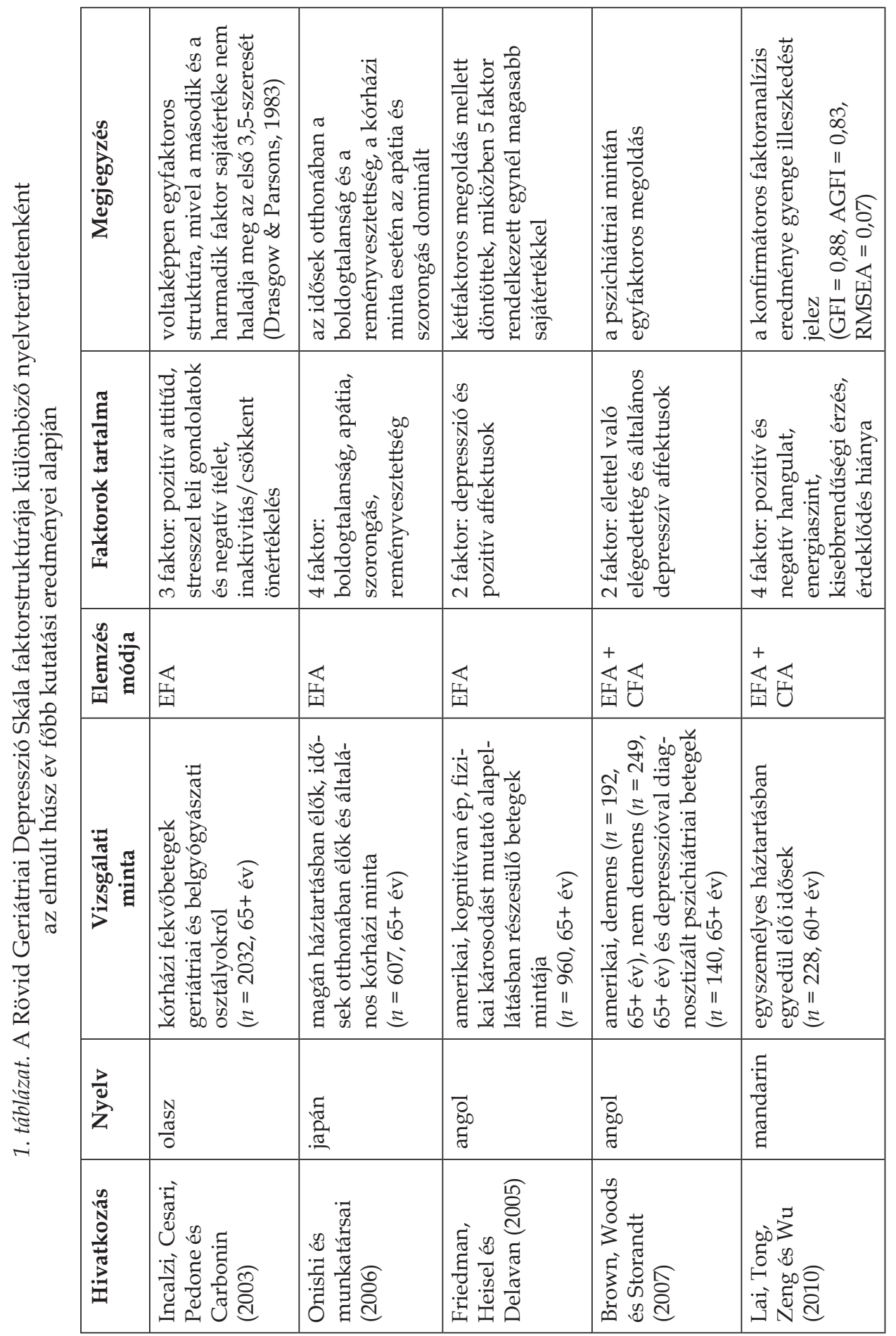




\begin{tabular}{|c|c|c|c|c|c|}
\hline 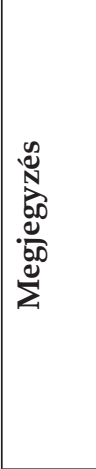 & 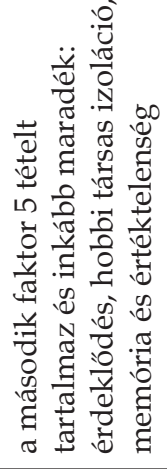 & & 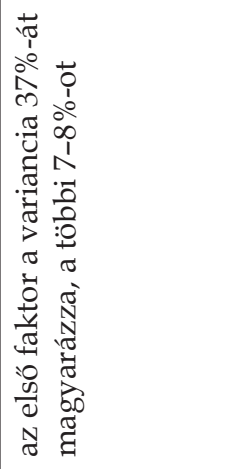 & 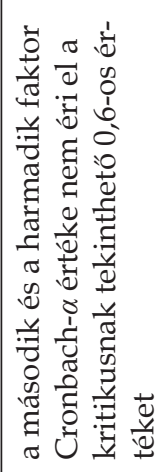 & 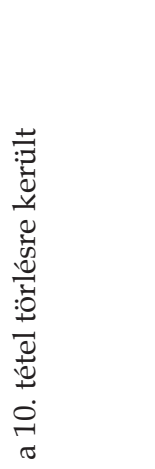 \\
\hline 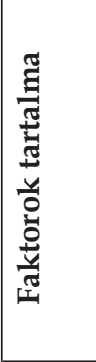 & 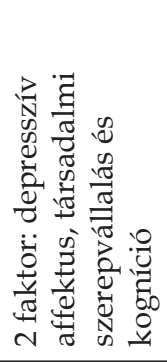 & 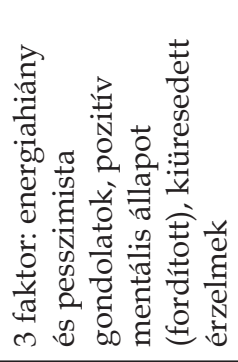 & 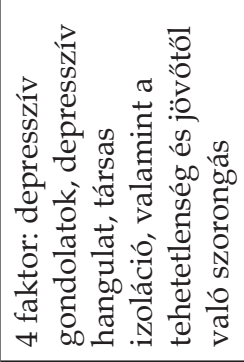 & 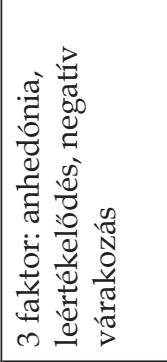 & 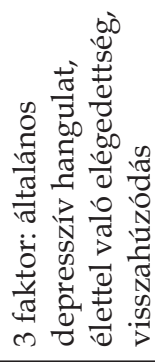 \\
\hline 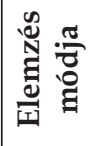 & 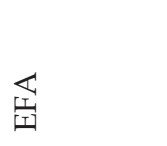 & 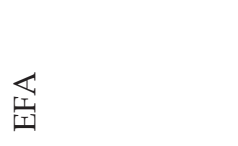 & 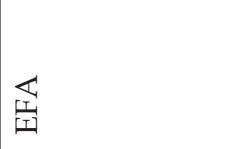 & 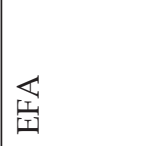 & 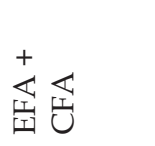 \\
\hline 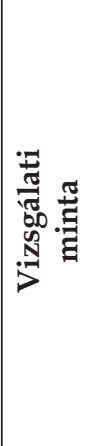 & 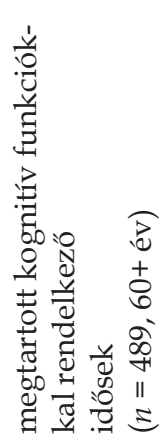 & 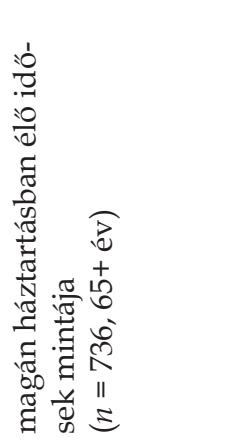 & 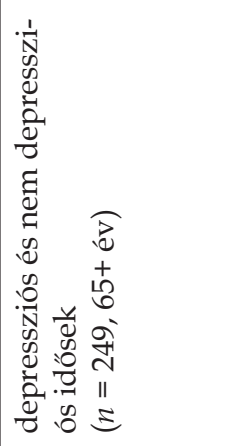 & 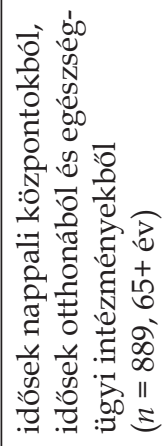 & 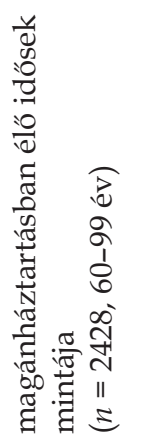 \\
\hline$\frac{2}{0}$ & 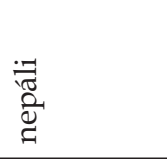 & 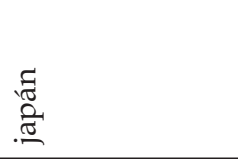 & \begin{tabular}{l}
0 \\
\multirow{J}{N}{} \\
$\omega$
\end{tabular} & 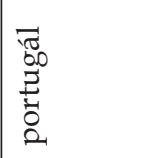 & 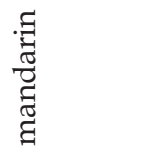 \\
\hline 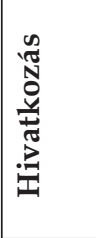 & 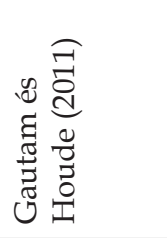 & 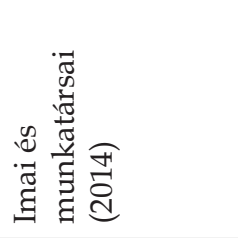 & 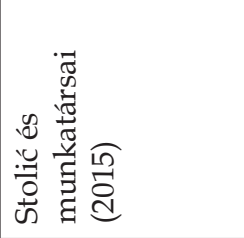 & 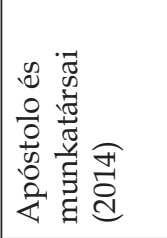 & 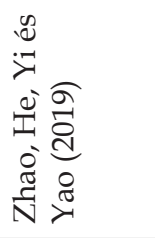 \\
\hline
\end{tabular}


A dimenzionalitás kérdése a gyakorlati felhasználás (pl. pontozás) szempontjából kiemelten fontos, ugyanakkor az 1. táblázat alapján megállapítható, hogy a nemzetközi eredmények tükrében a GDS-SF faktorstruktúrája jelentős variabilitást mutat a nyelvi és kulturális adaptációk, illetve a minta alapján. A két-, a három-, illetve a négyfaktoros struktúra tekinthető a leggyakoribb megoldásnak, azonban a sajátértékek több esetben inkább az egyfaktoros megoldást valószínúsítik (lásd pl. Incalzi és mtsai, 2003; Stolić és mtsai, 2015). Továbbá a konfirmátoros faktoranalízis mutatói sem jeleznek jó illeszkedést (lásd Lai és mtsai, 2010), valamint a legfrissebb, nagy elemszámú mintán történő elemzés eredményei alapján a 10. tétel törlése is indokolt (Zhao és mtsai, 2019). Mindez felhívja a figyelmet a depressziós tünetek konceptualizációjának nyelvi és kulturális különbségeire és a mintavétel fontosságára (Kim, DeCoster, Huang, \& Bryant, 2013). A fentiek alapján messzemenókig indokolt a Rövid Geriátriai Depresszió Skála magyar nyelvú változatának pszichometriai elemzése.

A 15 tételes Rövid Geriátriai Depresszió Skála magyar nyelvú fordítását Janka Zoltán adta közre (Pék, Égerházi, \& Kovács, 2003), azonban a kérdőív hazai alkalmazásával szerzett tapasztalatok még nem kerültek publikálásra. A jelen vizsgálatunk elsődleges célja a Rövid Geriátriai Depresszió Skála átfogó, normatív mintán történő pszichometriai elemzése, amely kiterjed a 15 tételes skála faktorszerkezetének részletes vizsgálatára, a tételek belső konzisztenciájának elemzésére, valamint a skála konstruktum- és konvergens validitásának vizsgálatára.

\section{Az online tér használata idôskorban}

Tanulmányuk másodlagos célkitúzése módszertani jellegú: arra a kérdésre keressük a választ, hogy az online térben való adatgyújtés mennyiben mérhető össze a papír-ceruza alapú tesztfelvételi móddal időskorban. Az online térben történő adatgyúités egyre inkább népszerú a társadalomtudományokban, hiszen költség- és időhatékony, könnyú adatbeviteli módot és rugalmas formátumot kínál, ahol a válasz függvényében további információ is rögzíthető (Granello \& Wheaton, 2004). Az idős, 65 év feletti populáció onlinetérhasználatát illetően azonban még hiányoznak az empirikus kutatások és a metaanalízisek, miközben egyre több, kifejezetten az idős populációt megcélzó online pszichológiai intervenciós program és platform érhető el (Khosravi, Rezvani, \& Wiewiora, 2016; Proyer, Gander, Wellenzohn, \& Ruch, 2014). Illetve további tény, hogy az Eurostat (2018) internethasználatra vonatkozó eredményei alapján Magyarországon az 55-74 éves korosztályon belül folyamatosan nő az internethasználók aránya: 2008-ban még csupán 25\%-uk, míg 2016-ban már 51\%-uk használta a világhálót (NMHH, 2018). 
A fenti kérdést azonban a módszertani aspektusán túl is érdemes vizsgálni, hiszen jól dokumentált tény, hogy az online tér használata az idősebb populáció esetében csökkenti a depresszió kockázatát (Cotten, Ford, Ford, \& Hale, 2012; Cotten, Ford, \& Hale, 2014; Lee \& Kim, 2014; Liao, Zhou, Liu, \& Wang, 2020; Sims, Reed, \& Carr, 2017). Liao és munkatársai (2020) friss áttekintése nyomán pontos képet kapunk a lehetséges hatásmechanizmusokat illetően. Ezeket az alábbiakban foglalhatjuk össze.

Az életkor előrehaladtával - kiváltképp a munkából való visszavonulást követően - a csökkenő mobilitás és a földrajzi távolság miatt beszúkülnek a társas kapcsolatok, fokozódik a társas és érzelmi magányosság. Azonban az internet lehetővé teszi a családdal, a barátokkal és a külvilággal való kapcsolattartást, ezáltal csökkenti a társas izolációt (Cotten, Anderson, \& McCullough, 2013; Khosravi és mtsai, 2016) és a magányosság érzését (Şar, Göktürkb, Turac, \& Kazazd, 2012). A társas részvétel elősegítésén keresztül növekszik a valahova tartozás és a társas támogatás érzése, amely különösen azok számára elónyös, akik krónikus fájdalomtól szenvednek és korlátozott a fizikai aktivitásuk (Mackichan, Adamson, \& Gooberman-Hill, 2013).

Az internet az idősebb emberek számára is fontos információforrást jelenthet: releváns egészségügyi ismeretek megszerzését szolgálja, továbbá hozzájárulhat betegségek megelőzéséhez, azok kezeléséhez (Zhang és mtsai, 2017), ezáltal csökkenti a depresszió kockázatát.

A kognitív funkciók és a depresszió közötti szoros kapcsolatra vonatkozó növekvő bizonyítékok (Levy és mtsai, 2018) újabb lehetséges magyarázatot adhatnak. Voltaképpen a digitális múveltség, az online térben történó információkeresés és -feldolgozás, valamint a tervezés és az internethasználat során felmerülő problémamegoldás a prefrontális kéreg fokozott aktivitásával függ össze (Small, Moody, Siddarth, \& Bookheimer, 2009). Az online játékok térbeli navigációja pedig növeli a hippokampális szürkeállományt (Kühn \& Gallinat, 2014). Mindkettó javítja az ember végrehajtó funkcióit. A kutatásokban összefüggést figyeltek meg a végrehajtó funkciók pozitív irányú változása és a depressziós tünetek mérséklődése között (pl. Anguera, Gunning, \& Arean, 2017; idézi Liao és mtsai, 2020).

Továbbá, a végrehajtó funkciók magukban foglalják a rumináció gátlását is, tehát a negatív gondolatokon való rágódás által szintén csökken a depresszió (Kühn, Berna, Lüdtke, Gallinat, \& Moritz, 2018). Egy amerikai felmérésben 77 éves átlagéletkorú időseket vizsgáltak mobilon is elérhető videójátékok (mint pl. sudoku, kirakós játékok, online színezők, madzsong) használata mentén. Eredményeik szerint azok az idősek, akik rendszeresen vagy legalább alkalmanként játszottak (a minta 35\%-a) mentálisan egészségesebbek voltak, alacsonyabb mértékú depresszió jellemezte őket és ritkábban éltek át negatív érzelmeket a nem játszókhoz képest (Allaire és mtsai, 2013). 
Végül, maguk az interneten elérhető kellemes tartalmak (pl. élvezetes zenék, szórakoztató videók, vicces képek) stimulálhatják a dopamin felszabadulását a striátumban, ily módon csökkentik a depressziós tüneteket (Wu, Gao, \& Li, 2017; idézi Liao és mtsai, 2020).

A fentiek alapján megállapítható, hogy a lehetséges magyarázó változók voltaképpen három fő komponens mentén szerveződnek: ezek a társas támogatás, a szelf-empowerment és a jóllét növelésének szerepét hangsúlyozzák (Kamalpour, Watson, \& Buys, 2020).

Másodsorban tehát arra a kérdésre keressük a választ, hogy az online adatfelvételi módban részt vevő vizsgálati személyek mintája, pontosabban annak életkora, iskolai végzettsége, életminősége és depresszióra vonatkozó előfordulási gyakorisága különbözik-e a kérdőívet hagyományos módon, papír-ceruza alapon kitöltő minta sajátosságaitól. Ezáltal közvetett úton arra is választ kaphatunk, hogy vajon az online tér használata idősebb korban együtt jár-e a depresszió alacsonyabb előfordulási gyakoriságával magyar idősek normatív mintáján.

\section{Módszerek}

\subsection{Résztvevők}

Keresztmetszeti, kérdőíves vizsgálatunk során a mintaválasztás nem valószínúségi, hozzáférhetőségi alapú kényelmi mintavétel volt, hólabdamódszerrel kiegészülve: nyugdíjasklubokban, idősek otthonában, valamint idősek számára múködtetett - a szabadidős tevékenységekhez kapcsolódó (pl. kertészkedés, színházba járás) - közösségi csoportokon keresztül értük el a vizsgálati személyeket. A mintába való beválasztási kritériumot a 65 év és afeletti életkor jelentette, míg a magas szociális kívánatosság kizáró tényezóként szerepelt (lásd továbbá a Méróeszközök és Alkalmazott statisztikai elemzések alfejezeteket). Második kérdésfeltevésünknek megfelelóen a vizsgálatban való részvétel online $(n=168)$, illetve papír-ceruza alapú $(n=147)$ tesztfelvétel keretében történt, informált hozzájárulással, önkéntes és anonim módon, ellenszolgáltatás nélkül. (Az online csoport esetében az internethasználat tágabb aspektusairól, pl. az eszközhasználat típusáról, annak gyakoriságáról vagy pontos tartalmáról nem gyújtöttünk részletes adatokat). Az adatgyújtés 2019. 01. 10. és 2019. 06. 22. között zajlott. A vizsgálatot az Egyesített Pszichológiai Kutatásetikai Bizottság jóváhagyta (az etikai engedély referenciaszáma: 2019/21).

A végső mintát alkotó válaszadók $(n=309$, online adatgyújtés: $n=167$, papír-ceruza adatgyújtés: $n=142)$ átlagéletkora 69,9 év (SD = 5,39 év; terjedelem: 65-92 év). Nemi eloszlás tekintetében a nők teszik ki a minta 79\%-át, 
a férfiak pedig a minta $21 \%$-át. A minta iskolában eltöltött évei számának átlaga 13,2 év (SD = 3,34 év; terjedelem: 6-21 év). Lakóhelyét tekintve a megkérdezettek 12\%-a Budapesten, 10\%-a megyeszékhelyen, $41 \%$-a városban, 36\%-a pedig (nagy)községben vagy falun él. Családi állapotát tekintve a minta 57\%-a házas, 27\%-a özvegy, 6\% vallotta magát egyedülállónak, 10\%-uk pedig elvált.

\subsection{Mérőeszközök}

A depressziós tünetegyüttes vizsgálatára a 15 tételes Rövid Geriátriai Depresszió Skálát (Geriatric Depression Scale; GDS-SF; Sheikh \& Yesavage, 1986; magyar változat: Perczel-Forintos, Ajtay, Barna, Kiss, \& Komlósi, 2018) alkalmaztuk. A kérdőív 10 egyenes és 5 fordított tételből áll. Az önkitöltős kérdőíven a vizsgált személyek igen/nem válaszadás formájában rögzíthetik válaszukat az egyes tételekkel kapcsolatban, aszerint, hogy hogyan érezték magukat az elmúlt hét során. A skála értékelése a következőképpen történik: minden válasz, amely a depressziós tünetek meglétére utal, 1 pontot kap, ahol az 1., 5., 7., 11., 13. tételek fordítottak. A pontszámítás a fordított tételek átkódolása után a tételekre adott válaszok összesítésével történik. A pontszámok három övezetbe sorolhatók: a normál tartományba az 5 pont alatti, a középsúlyos tartományba az 5-10 pont közötti érték, a súlyos tartományba a 10 pont feletti értékek tartoznak (Greenberg, 2012). A kérdőív Cronbach- $\alpha$ értéke 0,94, az ismételt méréses megbízhatósága szintén magasnak bizonyult (Sheikh \& Yesavage, 1986).

A 20 tételes Zung Önértékelő Depresszió Skála (Zung Self-Rating Depression Scale; ZSDS; Zung, 1965; magyar verzió: Simon, 1994) 10 egyenes és 10 fordított tételen, 4-fokú Likert-típusú skálán (a válaszlehetóségek végpontjai: nagyon ritkán [1], nagyon gyakran [4]) méri a depresszió összes tünetét, a szomatikus és a pszichés tünetcsoportokra koncentrálva. A skála egyenes és fordított itemeket egyaránt tartalmaz. A pontok összeadásával kapjuk meg a nyerspontok összegét, amelynek minimuma 20, maximuma 80 lehet. 48 pont fölött nem zárható ki a depresszió. A súlyosság foka szerint a pontszámok négy értékhatár mentén csoportosíthatók: 25-49 pont között normál, 50-59 pont között középsúlyos, 60-69 pont között mérsékelten súlyos, 70 pont és afölött pedig súlyos depresszióról beszélhetünk. A magyar validáló tanulmány alapján a skála megfelelő belső konzisztenciával rendelkezik (Simon, 1994). Jelen vizsgálat esetében a Cronbach- $\alpha$ értéke 0,76 .

Az életminőség mérésére az Egészségügyi Világszervezet Röviditett Életminőség Kérdöívét (World Health Organization Quality of Life; WHOQOLBREF; WHO, 1996; magyar változat: Paulik és mtsai, 2007) alkalmaztuk. 
A 26 tételes kérdőív az általános egészség érzése mellett négy tárgykör mentén szerveződik. 1. A fizikai skála a fájdalmat, a kezelésre szorulást, a személy erőnlétét és mozgási képességét, az egyén alvását, mindennapos életvitelét, valamint munkaképességét vizsgálja. 2. A pszichológiai dimenzió a pozitív érzéseken, az élet értelmességén, a koncentrációképességen, és az egyén önbecsülésén alapszik. 3. A társas kapcsolati tárgykör a személyes kapcsolatokat, a nemi életet, valamint a társas támogatást vizsgálja. 4. A környezeti tárgykör a biztonságérzetet, a fizikai védettséget, az alapvető szükségletek kielégítettségét mutatja. A válaszadás ötfokú Likert-típusú skálán történik az egyáltalán nem (1) és a teljesen (5) végpontok között. A magasabb pontszám jobb életminőséget jelez. A kérdóív belső konzisztenciája kiváló (Cronbach- $\alpha=0,93$; Paulik és mtsai, 2007). Jelen vizsgálatban az alskálák belső megbízhatóságát jelző Cronbach- $\alpha$ értéke a 0,72 és 0,91 közötti tartományban helyezkedik el.

A pszichológiai jóllétet a Rövidített WHO Jól-Lét kérdőívvel (Well-Being Index; WBI-5; Bech, 1996; magyar változat: Susánszky, Konkoly Thege, Stauder, \& Kopp, 2006) mértük. A kérdőív 5 tételére vonatkozó válaszadás négyfokú Likert-típusú skála segítségével történik az egyáltalán nem jellemző (0) és a teljesen jellemző (3) végpontok között. A magasabb pontszám jobb életminőségre utal, a kitöltók szubjektív megítélése alapján. A mérőeszköz megbízhatóan és érvényesen méri a pozitív életminőséget (Susánszky és mtsai, 2006). Jelen vizsgálat esetében a kérdőív Cronbach- $\alpha$ értéke 0,85 .

Az önmagukat jobb fényben feltüntetni kívánó vizsgálati személyek szúrésének érdekében alkalmaztuk a Caprara-féle Big Five Kérdőív Szociális Kivánatosság alskáláját (Caprara Big Five Questionnaire; BFQ-SZK; Caprara, Barbaranelli, Borgogni, \& Perugini, 1993; magyar változat: Rózsa, Kő, \& Oláh, 2006). A skála 12 egyenes tételt tartalmaz, a válaszadás ötfokú Likerttípusú skálán történik az egyáltalán nem értek vele egyet (1) és a teljesen egyet értek vele (5) végpontok között. A skálán elért magasabb pontszám torzított válaszadásra utal. A Szociális Kívánatosság alskála a pozitív, illetve a negatív irányú torzítás detektálására egyaránt alkalmas (Rózsa és mtsai, 2006). A skála megfelelő pszichometriai mutatókkal bír (Rózsa és mtsai, 2006), és a belső konzisztenciája jelen kutatás esetében is megfelelő: a Cronbach- $\alpha$ értéke 0,82.

\subsection{Alkalmazott statisztikai elemzések}

Az adatbázis tisztítása során kizárásra kerültek a mintából azok a személyek, akik a minta átlagához $(\mathrm{M}=40,57 ; \mathrm{SD}=7,3)$ képest magasabb szociális kívánatossággal rendelkeztek. Tehát azok a válaszadók, akiknek a pontszá- 
ma meghaladta az átlag plusz 1 szórástartományt, kizárásra kerültek $(n=6$, 1 férfi és 5 nő) a teszteredményekben megmutatkozó fokozott válaszmeghamisító tendencia miatt.

Az adatelemzés eredményeit öt lépésben szemléltetjük. Elsőként parallelelemzést végeztünk, hogy meghatározzuk a Rövid Geriátriai Depresszió Skála (GDS-SF) lehetséges dimenzióinak számát és ellenőrizzük a tételek dimenziókba szerveződését. A Horn (1965) által bevezetett parallelelemzés egy olyan szimulációs módszer, amely lehetőséget ad arra, hogy csak azokat a dimenziókat tartsuk meg, amelyek sajátértéke nagyobb, mint a random, korrelálatlan változókból képzett sajátérték. Igen-nem válaszformátumból származó változóink esetében a normalitás sérül, így polikorikus korrelációt alkalmaztunk (Muthén \& Kaplan, 1985, 1992). A parallelelemzést a súlyozatlan legkisebb négyzetek (Robust Unweighted Least Squares) technikával és 500 véletlenszerúen generált korrelációs mátrix segítségével készítettük el (Timmerman \& Lorenzo-Seva, 2011). A 15 tételből álló GDSSF kérdőív egydimenziós szerkezetének alátámasztására a FACTOR program által felkínált egydimenziós kongruencia mutatót (Unidimensional Congruence, UniCo) és a megmagyarázott közös varianciahányadot (Explained Common Variance, ECV) alkalmaztuk. Az UniCo esetében a módszertani ajánlásokban megfogalmazott 0,95-ot, míg az ECV esetében 0,85-ot tekintettük kritériumnak (Ferrando \& Lorenzo-Seva, 2018). A kérdőív belső megbízhatóságát Cronbach- $\alpha$ mutató számításával vizsgáltuk.

Második lépésben a GDS-SF leíró statisztikáit adjuk közre, továbbá kétváltozós elemzések keretében teszteljük a demográfiai változókkal való kapcsolatát. A nemek közötti különbség meghatározása független mintás t-próbával történt. A hatásméret meghatározására az átlagok különbségén alapuló Cohen-féle $d$-mutatót használtuk. Ennek értéke 0,20 esetében kicsi hatásra, 0,50 esetében közepes erősségú hatásra, 0,80 felett pedig nagymértékú hatásra utal (Cohen, 1988). A skála életkorral és iskolai végzettséggel való kapcsolatának felmérésére Pearson-féle korrelációs elemzést alkalmaztunk, a központi határeloszlás tétel értelmében (Wilcox, 2010). A korrelációs együtthatók értelmezése során az alábbi felosztást vettük alapul: 0,3 alatt gyenge, 0,3-0,5 között közepes erősségü, 0,5 felett pedig erős a kapcsolat (Cohen, 1988).

A harmadik lépés során a GDS-SF validitását a geriátriai depresszióval összefüggésbe hozható, korábban már validált kérdőívek - Zung Önértékelő Depresszió Skála, az Egészségügyi Világszervezet Röviditett Életminóség Kérdöive, Röviditett WHO Jól-Lét kérdôiv - Pearson-féle korrelációs mátrixa alapján értékeltük.

A negyedik lépésben az adatfelvétel módjára, az online és az offline adatgyújtésre vonatkozó összehasonlítást teszteltük a nemi hovatartozás, az életkor és az iskolai végzettség kontrollálása mellett, kovarianciaelemzés 
segítségével. A különbség hatásméretének becslésére parciális $\eta^{2}$-számítást alkalmaztunk, ahol 0,01 alatt kicsi a hatás, 0,06 közepes, míg a 0,14 nagy hatást jelez (Field, 2005).

Végül a depresszió előfordulási gyakoriságára vonatkozó adatokat adjuk közre jelen minta vonatkozásában, továbbá az online és a papíralapú adatfelvétel tükrében vizsgáljuk a depressziós esetek számát. A csoportok öszszehasonlítása $\chi^{2}$-próbával történt. A különbség hatásmértékének becslésére a Cramér-féle $V$ kiszámítását alkalmaztuk. Ennek értelmezése a szabadsági fok függvényében eltérő. Esetünkben: 0,07 gyenge, 0,21 közepes, 0,35 pedig erős hatást jelez (Cramér, 1946).

A statisztikai elemzéseket az SPSS 23 (IBM Corp., 2013) és a FACTOR (Lorenzo-Seva \& Ferrando, 2006, 2013) programokkal végeztük.

\section{Eredmények}

\subsection{A Rövid Geriátriai Depresszió Skála faktorszerkezete}

A GDS-SF dichotóm válaszformátuma miatt a faktorelemzésnél polikorikus korrelációt alkalmaztunk. A valós adatmátrixunk első faktora az összvariancia $65,4 \%$-át magyarázta, a második és a harmadik faktorok pedig $8,2 \%$-ot és 5,5\%-ot. A véletlenszerúen és korrelálatlan változókból képzett mátrixok első faktora átlagosan $15,8 \%$-ot, a második $13,8 \%$-ot, míg a harmadik $12,2 \%$-ot magyarázott. Láthatjuk, hogy a valós adatok mátrixán nyert 65,4\%-os magyarázott variancia lényegesen meghaladja a véletlenszerúen kapott értéket (15,8\%), ezzel szemben a második és harmadik faktor $(8,2 \%$ és 5,5\%) már nem magyaráz olyan mértékú varianciát, amely a véletlenszerúen szimulált eredményeket meghaladná. Eredményünk alapján a normatív mintán végzett parallelelemzésen alapuló szimulációs módszer így 1 szignifikáns dimenzió meglétét jelezte. Az egydimenziós kongruencia mutató $($ UniCo $=0,984)$ és a magyarázott közös varianciahányad $(\mathrm{ECV}=$ 0,921 ) meghaladták a kritériumokat (UniCo > 0,95 és ECV > 0,85), így a parallelelemzés eredményeként a GDS-SF 15 tételének faktorszerkezete egydimenziósnak tekinthetó.

A 2. táblázat szemlélteti a GDS-SF kérdőív faktorszerkezetét. A táblázat utolsó oszlopában a kommunalitás $(H)$ mutatókat tüntettük fel, amelyek azt fejezik ki, hogy az egyes tételek varianciáját a faktorok mennyire ragadják meg.

Az egyes tételek faktorsúlya 0,50 és 0,97 közöttinek bizonyult. A legnagyobb töltéssel a 3. állítás szerepel: „Üresnek érezte az életét?”, míg legalacsonyabbal a 10. tétel: „Azt gondolja, hogy emlékezőképessége az átlagnál rosszabb volt." A 10. tétel varianciáját a faktor 25\%-ban magyarázza. 
A GDS-SF kérdőív magyar verziójának reliabilitásvizsgálata során kapott Cronbach- $\alpha$ mutató kiváló belső megbízhatóságot mutat: értéke 0,95.

2. táblázat. A Rövid Geriátriai Depresszió Skála faktorstruktúrája

\begin{tabular}{|c|c|c|}
\hline Tételek & Faktorsúly & Kommunalitás \\
\hline 1. Alapvetően elégedett volt az életével?* & 0,84 & 0,71 \\
\hline 2. Elvesztette az érdeklődését a szokott dolgai iránt? & 0,85 & 0,72 \\
\hline 3. Üresnek érezte az életét? & 0,97 & 0,93 \\
\hline 4. Gyakran unatkozott? & 0,90 & 0,82 \\
\hline 5. Általában jó volt a hangulata?* & 0,89 & 0,79 \\
\hline $\begin{array}{l}\text { 6. Tartott attól, hogy valamilyen szerencsétlenség } \\
\text { fogja érni? }\end{array}$ & 0,57 & 0,33 \\
\hline 7. Általában boldognak érezte magát?* & 0,89 & 0,80 \\
\hline 8. Gyakran érezte magát tehetetlennek? & 0,89 & 0,79 \\
\hline $\begin{array}{l}\text { 9. Jobban szeretett otthon maradni, mint kimozdulni } \\
\text { és programokat csinálni? }\end{array}$ & 0,53 & 0,28 \\
\hline $\begin{array}{l}\text { 10. Azt gondolja, hogy emlékezőképessége az átlagnál } \\
\text { rosszabb volt? }\end{array}$ & 0,50 & 0,25 \\
\hline 11. Azt gondolta, hogy nagyszerú dolog most élni?* & 0,74 & 0,55 \\
\hline 12. Haszontalannak, értéktelennek érezte magát? & 0,88 & 0,78 \\
\hline 13. Úgy érezte, hogy tele van energiával?* & 0,71 & 0,50 \\
\hline 14. Úgy érezte, hogy reménytelen a helyzete? & 0,91 & 0,82 \\
\hline $\begin{array}{l}\text { 15. Úgy érezte, az emberek többségének jobban megy } \\
\text { a sora, mint Önnek? }\end{array}$ & 0,60 & 0,36 \\
\hline Cronbach- $\alpha$ & & 0,95 \\
\hline
\end{tabular}

Megjegyzés: a csillaggal jelölt tételek fordítottak.

\subsection{Leíró statisztikák}

A 3. táblázat a demográfiai jellemzők és az alkalmazott kérdőívek leíró statisztikai adatait szemlélteti nemek szerinti bontásban. Az eredmények szerint szignifikáns nemi különbség egyedül az életkorban mutatkozik a férfiak és a nők között, más szavakkal, jelen minta férfi válaszadói - átlagosan közel két évvel - idősebbek a női kitöltőknél, amely különbség statisztikailag kicsinek tekinthetó. 
3. táblázat. A demográfiai jellemzők és az alkalmazott kérdóívek leíró statisztikája nemek szerinti bontásban

\begin{tabular}{|c|c|c|c|c|c|c|}
\hline \multirow[t]{2}{*}{$\begin{array}{l}\text { Vizsgált } \\
\text { változó }\end{array}$} & $\begin{array}{l}\text { Teljes minta } \\
\quad(n=309)\end{array}$ & $\begin{array}{l}\text { Férfiak } \\
(n=63)\end{array}$ & $\begin{array}{c}\text { Nók } \\
(n=246)\end{array}$ & \multicolumn{2}{|c|}{$\begin{array}{c}\text { Statisztikai } \\
\text { próba }\end{array}$} & \multirow{2}{*}{$\begin{array}{c}\text { Hatás- } \\
\text { méret }\end{array}$} \\
\hline & \multicolumn{3}{|c|}{ átlag (SD) } & $t$ & $p$ & \\
\hline \multicolumn{7}{|l|}{$\begin{array}{l}\text { Demográfiai } \\
\text { változók }\end{array}$} \\
\hline Életkor & $69,90(5,4)$ & $71,39(5,56)$ & $69,52(5,30)$ & 2,48 & 0,014 & 0,34 \\
\hline Iskolai évek & $13,22(3,36)$ & $13,35(3,76)$ & $13,19(3,25)$ & 0,34 & 0,733 & 0,04 \\
\hline \multicolumn{7}{|l|}{ Életminőség } \\
\hline Fizikai & $12,63(1,61)$ & $12,63(1,72)$ & $12,64(1,59)$ & 0,024 & 0,98 & 0,00 \\
\hline Társas & $13,56(3,06)$ & $13,15(2,81)$ & $13,66(3,11)$ & $-1,18$ & 0,238 & 0,15 \\
\hline Pszichológiai & $13,31(1,94)$ & $13,15(2,07)$ & $13,36(1,90)$ & $-0,74$ & 0,462 & 0,09 \\
\hline Környezeti & $14,16(2,44)$ & $14,02(2,47)$ & $14,20(2,44)$ & $-0,52$ & 0,604 & 0,04 \\
\hline Jóllét & $8,71(3,27)$ & $8,20(3,35)$ & $8,83(3,21)$ & $-1,37$ & 0,172 & 0,19 \\
\hline \multicolumn{7}{|l|}{ Depresszió } \\
\hline Zung Önértékelő DS & $41,9(7,17)$ & $42,08(7,38)$ & $41,87(7,13)$ & 0,21 & 0,833 & 0,03 \\
\hline Geriátriai DS & $3,47(3,84)$ & $4,21(3,63)$ & $3,28(3,88)$ & 1,71 & 0,089 & 0,25 \\
\hline
\end{tabular}

Megjegyzés: DS = Depresszió Skála.

\subsection{A Rövid Geriátriai Depresszió Skála validitásvizsgálata}

A 4. táblázatban bemutatjuk a GDS-SF kérdőív vizsgált változókkal való együttjárásait, illetve a Zung Önértékelő Depresszió Skála vizsgált változókkal való korrelációs együtthatóit, a két depressziót mérő kérdőív jellegzetességeinek - hasonlóságainak és különbözőségeinek - pontosabb feltárása érdekében.

A korrelációs elemzések eredménye alapján a GDS-SF segítségével mért időskori depresszió szignifikáns, gyenge, pozitív irányú kapcsolatot mutat az életkorral, illetve szignifikáns, gyenge, negatív irányú együttjárást az iskolában eltöltött évek számával. A Geriátriai Depresszió Skála és az életminőség valamennyi, általunk mért aspektusa között szignifikáns, erős, negatív irányú korreláció jellemző. A GDS-SF és a jóllét között ugyancsak szigni- 
fikáns, erős, negatív irányú kapcsolat mutatkozik. A GDS-SF konstruktum validitást igazolja az is, hogy szignifikáns, erős, pozitív irányú kapcsolatban áll a Zung Önértékelő Depresszió Skálával. A GDS-SF és a Zung Önértékelő Depresszió skála korrelációs együtthatóinak összehasonlítása alapján megállapítható, hogy nagyságrendjét tekintve a GDS-SF az iskolai végzettséggel kevésbé szorosan korrelál, mint a Zung Önértékelő Depresszió Skála, ugyanakkor az életkor, az életminőség valamennyi aspektusa és a jóllét tekintetében ekvivalensek a kapcsolat irányát és erejét jelző korrelációs együtthatók.

4. táblázat. A Rövid Geriátriai Depresszió Skála és a Zung Önértékelő Depresszió Skála korrelációs együtthatói a vizsgált változókkal

\begin{tabular}{|l|c|c|}
\hline \multicolumn{1}{|c|}{$\begin{array}{c}\text { Vizsgált } \\
\text { változó }\end{array}$} & $\begin{array}{c}\text { Geriátriai } \\
\text { Depresszió Skála }\end{array}$ & $\begin{array}{c}\text { Zung Önértékelő } \\
\text { Depresszió Skála }\end{array}$ \\
\hline Demográfiai változók & \multicolumn{2}{|c|}{} \\
\hline Életkor & $0,10^{*}$ & $0,15^{*}$ \\
\hline Iskolai évek & $-0,20^{* *}$ & $-0,31^{* *}$ \\
\hline Életminóség & \multicolumn{2}{|c|}{} \\
\hline Fizikai & $-0,59^{* *}$ & $-0,59^{* *}$ \\
\hline Társas & $-0,59^{* *}$ & $-0,60^{* *}$ \\
\hline Pszichológiai & $-0,59^{* *}$ & $-0,60^{* *}$ \\
\hline Környezeti & $-0,61^{* *}$ & $-0,64^{* *}$ \\
\hline Jóllét & $-0,71^{* *}$ & $-0,77^{* *}$ \\
\hline Depresszió (Zung Önértékelő DS) & $0,74^{* *}$ & - \\
\hline
\end{tabular}

Megjegyzés: Pearson-féle korrelációs együtthatók. ${ }^{*} p<0,05 ;{ }^{* *} p<0,001$. DS = Depresszió Skála.

\section{Az idóskori depresszió elófordulási gyakoriságának vizsgálata a jelen mintában}

A Rövid Geriátriai Depresszió Skálához, valamint a Zung Önértékelő Depresszió Skálához (ZSDS) tartozó küszöbértékek alapján megvizsgáltuk, hogy a depresszió súlyosságának vonatkozásában miként jellemezhető a teljes minta. Mindezt az 1. ábra szemlélteti. Az összehasonlíthatóság érdekében a ZSDS középsúlyos (50-59 pont) és mérsékelten súlyos (60-69) övezetét összevontuk és középsúlyos kategóriaként jelöltük a diagramon. 
A GDS-SF kérdőív segítségével mért középsúlyos depresszió gyakorisága 13,4\%, míg a súlyos depresszió előfordulási gyakorisága 9,4\% a jelen mintában. A minta 77,3\%-a a normál övezetbe sorolható a depresszió szempontjából. A Zung Önértékelő Depresszió Skálával mérve a depresszió tekintetében egészségesnek tekinthető a minta 83,9\%-a, ugyanakkor ez a kérdőív nem azonosított súlyosan depressziós vizsgálati személyt. Szignifikáns különbséget találtunk a Zung Önértékelő Depresszió Skála és a Rövid Geriátriai Depresszió Skála által mért depresszió súlyossági fokozatainak gyakorisági adataiban $\left(\chi^{2}(2),=30,69, p<0,001\right.$; Cramér-féle $\left.V=0,22\right)$. A GDS-SF nagyobb arányban jelzi a súlyos depressziós eseteket.

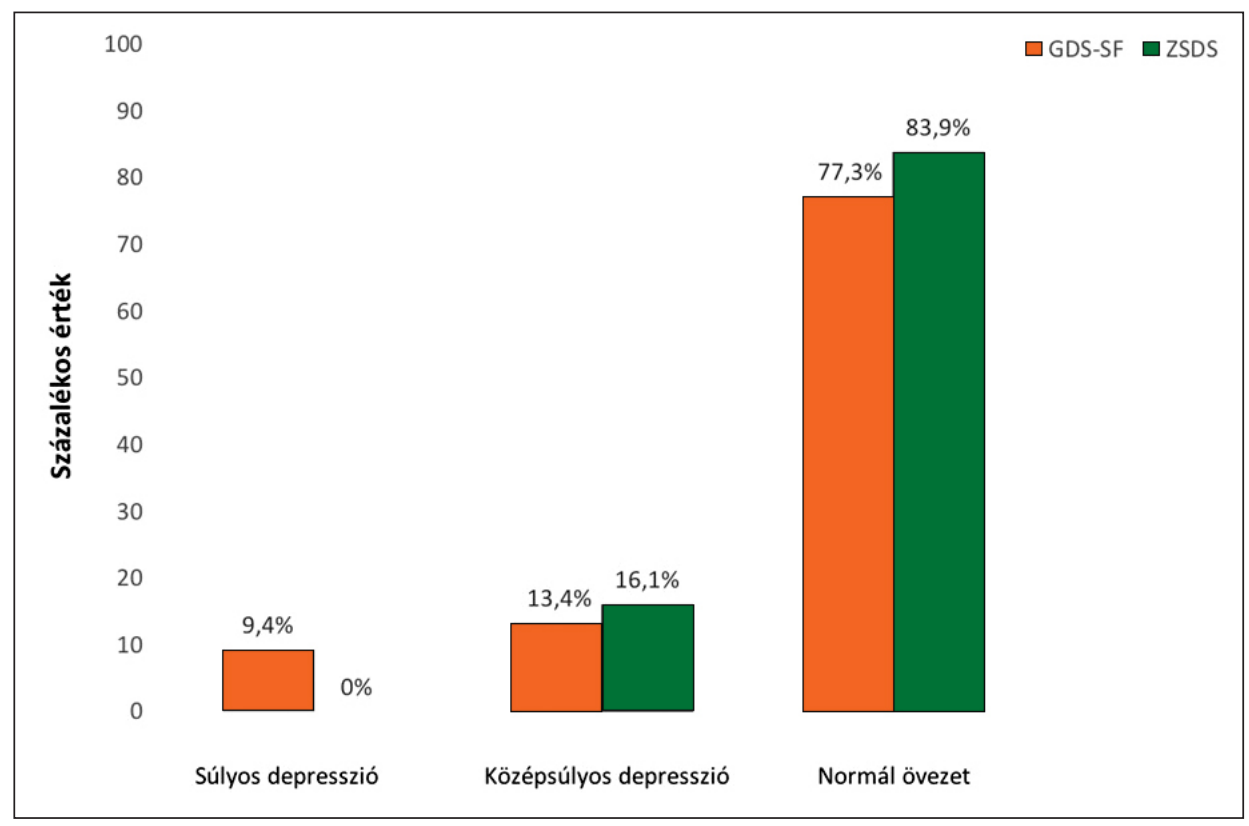

1. ábra. A depresszió százalékos eloszlása

a Rövid Geriátriai Depresszió Skála és a Zung Önértékeló Depresszió Skála által meghatározott súlyossági kategóriák vonatkozásában a jelen mintán

Megjegyzés: GDS-SF = Rövid Geriátriai Depresszió Skála, ZSDS = Zung Önértékeló Depresszió Skála.

\section{Az adatfelvétel módjára vonatkozó statisztikai elemzés}

Kutatásunk újszerúségét adta az adatfelvétel eltérő módjából származó összehasonlító elemzés. Az 5. táblázat az online és a papír-ceruza-alapú tesztfelvétel mentén hasonlítja össze a vizsgálati személyek demográfiai változóit. 
5. táblázat. Az adatgyűjtés módjának kapcsolata egyes demográfiai változókkal

\begin{tabular}{|c|c|c|c|c|c|}
\hline \multirow[t]{2}{*}{$\begin{array}{l}\text { Vizsgált } \\
\text { változó }\end{array}$} & $\begin{array}{c}\text { Online kitöltés } \\
\qquad(n=142)\end{array}$ & $\begin{array}{l}\text { Papír-ceruza- } \\
\text { alapú }\end{array}$ & \multicolumn{2}{|c|}{$\begin{array}{c}\text { Statisztikai } \\
\text { próba }\end{array}$} & \multirow{2}{*}{$\begin{array}{c}\text { Hatás- } \\
\text { méret }\end{array}$} \\
\hline & \multicolumn{2}{|c|}{ átlag (SD) } & $t$ & $p$ & \\
\hline \multicolumn{6}{|c|}{ Demográfiai változók } \\
\hline Életkor & $68,16(4,20)$ & $71,95(5,92)$ & 6,55 & $<0,001$ & 0,72 \\
\hline Iskolai évek & $14,16(3,12)$ & $12,12(3,30)$ & $-5,56$ & $<0,001$ & 0,64 \\
\hline
\end{tabular}

Az 5. táblázat alapján megállapítható, hogy az online és a papír-ceruza alapon válaszoló csoport az életkor és az elvégzett osztályok számát tekintve szignifikánsan, közepes hatásmérettel különbözik egymástól. Más szavakkal, a tesztbattériát papír-ceruza alapon kitöltő vizsgálati személyek átlagosan közel négy évvel - idősebbek a kérdőívcsomagot online formában kitöltő társaiknál, valamint az iskolában eltöltött éveik átlagos száma is alacsonyabb esetükben (két osztállyal alacsonyabb az iskolai végzettségük). Éppen ezért a nemet, az életkort és az iskolázottságot kontroll alatt tartva végeztük a két összehasonlító elemzést az életminőség, a jóllét és a depreszszió mentén. Az erre vonatkozó többszempontos kovarianciaanalízis eredményeit a 6. táblázat szemléleti.

6. táblázat. Az online és a papír-ceruza-alapú adatgyứjtés módjára vonatkozó összehasonlító elemzés, kontroll alatt tartva a nem, az életkor és az iskolai végzettség hatását

\begin{tabular}{|c|c|c|c|c|}
\hline \multirow{2}{*}{$\begin{array}{l}\text { Vizsgált } \\
\text { változó }\end{array}$} & Online kitöltés & Papír-ceruza-alapú & \multicolumn{2}{|c|}{ Statisztikai próba } \\
\hline & \multicolumn{2}{|c|}{ átlag (SD) } & $F$ & $p$ \\
\hline \multicolumn{5}{|l|}{ Életminőség } \\
\hline Fizikai & $12,62(1,55)$ & $12,64(1,69)$ & 2,15 & 0,144 \\
\hline Társas & $13,47(3,09)$ & $13,67(3,03)$ & 2,41 & 0,143 \\
\hline Pszichológiai & $13,44(1,83)$ & $13,16(2,04)$ & 0,14 & 0,708 \\
\hline Környezeti & $14,28(2,43)$ & $14,01(2,45)$ & 0,02 & 0,890 \\
\hline Jóllét & $8,92(3,06)$ & $8,44(3,44)$ & 0,03 & 0,870 \\
\hline \multicolumn{5}{|l|}{ Depresszió } \\
\hline Zung Önértékelő DS & $41,11(6,68)$ & $42,79(7,63)$ & 0,005 & 0,943 \\
\hline Geriátriai DS & $3,26(3,74)$ & $3,72(3,95)$ & 0,10 & 0,750 \\
\hline
\end{tabular}

Megjegyzés: DS = Depresszió Skála. 
A 6. táblázat eredményei alapján látható, hogy a papír-ceruza alapon és az online módon kitöltő́k között egyetlen változó sem jelez szignifikáns különbséget, amennyiben kontroll alatt tartjuk az életkor és az iskolai végzettség hatását. Tételszinten vizsgálva a két csoport közötti különbségeket, a fizikai életminőség két itemében találunk szignifikáns eltérést. Az online módon válaszolók úgy érzik, hogy a testi fájdalom nagyobb mértékben akadályozza óket tevékenységükben (3. tétel: $F(1,308)=9,09, p<0,05$; par. $\left.\eta^{2}=0,03\right)$. Továbbá, mindennapos életvitelük során nagyobb szükségük van orvosi kezelésre (4. tétel: $F(1,308)=24,93, p<0,001$; par. $\eta^{2}=0,08$ ).

A 2. ábrán bemutatásra kerül a depresszió előfordulási gyakorisága a teljes mintára vonatkozóan. Ezt követően az eltérő adatfelvételi csoportok öszszehasonlítását mutatjuk be. A 2. ábra adatai jelzik a Rövid Geriátriai Depresszió Skála értéktartományai alapján normális-középsúlyos-súlyos övezetbe eső vizsgálati személyek százalékos megoszlását az adatfelvétel eltérő módja alapján. Az összehasonlíthatóság érdekében a korábbi protokollt követtük most is: a Zung Önértékelő Depresszió Skála középsúlyos (50-59 pont) és mérsékelten súlyos (60-69 pont) övezetét összevontuk és középsúlyos kategóriaként jelöltük a diagramon.

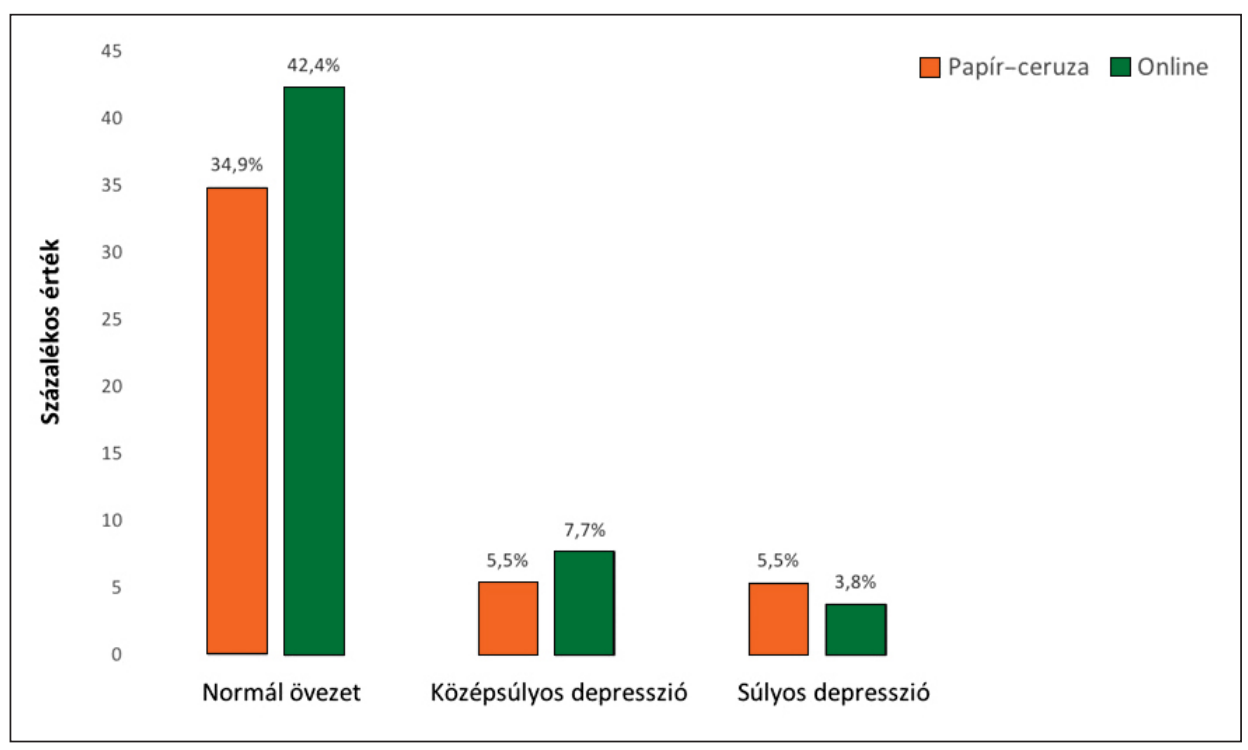

2. ábra. A depresszió elófordulási gyakorisága a papír-ceruza-alapú és az online módon kitöltők esetén

A papír-ceruza-alapú és az online adatgyújtésben részt vevő vizsgálati személyek körében a GDS-SF alapján mért depresszió előfordulási gyakoriságában nem találunk szignifikáns különbséget $\left(\chi^{2}(2)=2,26, p=0,323\right.$; 
Cramér-féle $V=0,061)$. A depresszió előfordulási gyakoriságát a két csoport vonatkozásában a Zung Önbevallásos Depresszió Skála segítségével is ellenőriztük. A statisztikai próba itt sem jelez szignifikáns különbséget $\left(\chi^{2}(2)\right.$ $=3,22, p=0,201$; Cramér-féle $V=0,069$ ).

\section{Megbeszélés}

Jelen tanulmány elsődleges célja a rövid, 15 tételes Geriátriai Depresszió Skála (GDS-SF) pszichometriai vizsgálata, amelyet az indokol, hogy a depressziót mérő kérdőívek közül kifejezetten idős populációra dolgozták ki és nem tartalmaz szomatikus tünetekre vonatkozó tételeket, amelyek az életkor előrehaladtát vagy a romló fizikai állapotot kísérik. A GDS-SF faktorszerkezetére, reliablitására és validitására vonatkozó kutatásunkat normatív mintán, keresztmetszeti elrendezésben vizsgáltuk 65 éves és afeletti idősek populációján.

A kérdốv faktorstruktúrájának feltárása során a parallelelemzésen alapuló szimulációs módszert használtuk, amely egyetlen szignifikáns dimenzió meglétét jelezte. Az egydimenziós kongruencia mutató és a megmagyarázott közös varianciahányad értéke is meghaladta az elózetesen rögzített kritériumértékeket, így a GDS-SF magyar változatának faktorszerkezete egydimenziósnak tekinthető. Az egyetlen faktor az összvariancia $65 \%$-át magyarázza. A leggyengébb kommunalitást a 10. tétel jelzi, amely azonban eléri az elvárt kommunalitás alsó határát (Székelyi \& Barna, 2002). Eredményeink illeszkednek Zhao és munkatársai (2019) kínai mintán végzett nagy elemszámú kutatási eredményével, akik az alsó határt el nem érő kommunalitás miatt a 10. tételt törölték is a kérdő́ivből. A Rövid Geriátriai Depresszió Skála Cronbach- $\alpha$ mutatója kiváló belső konzisztenciát jelez a mintánkban.

Az életkor vonatkozásában megállapítható, hogy az időskori depresszió gyenge, pozitív irányú kapcsolatot mutat az életkorral, illetve gyenge, negatív irányú együttjárást az iskolában eltöltött évek számával. Ezen eredmények egybevágnak a nemzetközi adatokkal, valamint azzal, hogy az életkornak vagy az iskolázottságnak nagyobb magyarázó ereje van, mint a nemi hovatartozásnak (Girgus, Yang, \& Ferri, 2017; Lee, Park, \& Chey, 2018). A GDS-SF nem jelzett szignifikáns nemi különbséget a férfiak és a nók között jelen mintán. Ezen adatok hasonlóak például Jang, Small és Haley (2010) eredményéhez, amely szerint a nemi hovatartozás nem szignifikáns előrejelzője a depressziónak idős korban, koreai és amerikai mintán sem. Ausztrál kutatók sem találtak szignifikáns nemi különbséget időseknél a depresszió vonatkozásában, amikor kontrollálták a kognitív funkciókat, a fizikai állapotot és az iskolai végzettséget (Pachana, McLaughlin, Leung, 
Byrne, \& Dobson, 2012). A magyarázat abban rejlik, hogy a nők és a férfiak depresszió szintje az életkor előrehaladtával közelít egymáshoz: 50-60 éves korukban a nők szignifikánsan magasabb depressziót mutatnak a férfiakhoz képest, azonban ez a különbség a 70 éves kor utáni életszakaszban eltúnik. Az idősebb korosztályban a férfiak és a nők depressziószintje közötti konvergenciát az okozza, hogy a hatvanas éveik közepétól a férfiak depreszsziós tüneteinek száma meredekebben emelkedik, mint a nőké (Sutin és mtsai, 2013).

A validitásra vonatkozó korrelációs elemzések egyértelmú bizonyítékát nyújtják a magyar adaptáció sikerességének. Az eredmények alátámasztják a skála konstruktum validitását: a magasabb depresszió értékek alacsonyabb pszichológiai jólléttel, valamint alacsonyabb életminőség-mutatókkal korrelálnak. Más szavakkal, a depressziós egyének általános közérzete és önbecsülése alacsonyabb, fizikai értelemben nagyobb mértékú fájdalomról, rosszabb alvásminőségről és kisebb erónlétról számolnak be, emellett elégedetlenebbek a társas kapcsolataikkal, valamint a közvetlen fizikai környezetükkel. Mindez kiemelt jelentőségú, hiszen a depresszió esetében ismert, hogy jelentősen rontja az életminőséget, továbbá számos krónikus betegségcsoportban növeli a morbiditást és a mortalitást (Torzsa, Szeiffert, Dunai, Kalabay, \& Novák, 2009). A jelen kutatás erénye, hogy ellenóriztük a GDSSF konkurens validitását is: a GDS-SF és a Zung Önértékelő Depresszió Skála egyidejú felvételével teszteltük a két mérőeszköz közötti együttjárást, amely kellóen magasnak mutatkozott. Ezen felül e két depresszió kérdőív más skálákkal való korrelációs együtthatói alapján megállapítható, hogy az életminőség valamennyi aspektusa és a jóllét tekintetében is ekvivalensek a kapcsolat irányát és erejét jelző korrelációs együtthatók. Ily módon igazoltuk a Rövid Geriátriai Depresszió Skála konkurens validitását.

Szintén a GDS-SF érvényessége melletti érv, hogy az általa mért középsúlyos depresszió előfordulási gyakorisága 13,4\%, míg a súlyos depresszióé 9,4\% a jelen mintában. Tehát a kérdőívvel nyert adatok az időskori depreszszió előfordulási gyakoriságának vonatkozásában - az átlagéletkort és a minta életkori terjedelmét figyelembe véve - illeszkednek a nemzetközi adatokhoz (Forlani és mtsai, 2014). Megállapítottuk továbbá, hogy szignifikáns különbség mutatkozik a Zung Önértékelő Depresszió Skála és a Rövid Geriátriai Depresszió Skála által meghatározott depresszió előfordulási gyakorisági adataiban. Ennek alapján a GDS-SF a minta 6,5\%-nál előbb jelzi a depresszió meglétét, mint a Zung-féle skála, illetve a vizsgálati személyek 9\%-ának állapotát súlyosabbnak detektálja. Mindez utalhat arra, hogy a skála túlbecsüli a depresszió kockázatát, de lehet a szenzitivitás jele is. A kérdésre a választ a specificitás vizsgálata adhatja meg, amely megmutatja, hogy a GDS-SF milyen megbízhatóan azonosítja azokat, akiket nem jelle- 
mez depresszió. A szenzitivitás természetesen önmagában nem elegendő, megfelelő specificitás mellett dönthetünk csak normatív mintán - detektálási céllal történő - alkalmazása mellett. Egy koreai kutatásban például a depresszió szürésére szolgáló GDS-SF küszöbértékét 8 pontnál jelölték ki, ezzel 96,3\%-os szenzitivitást és 76\%-os specificitást értek el (Bae \& Cho, 2004).

A kapott eredmények alapján a GDS-SF kérdőív tehát validnak bizonyult normatív mintán, ezért egy későbbi kutatásunk céljaként túztük ki a skála különböző pszichés és szomatikus betegpopulációkon való alkalmazásának ellenőrzését és ROC analízis végzését a diagnosztikai hatékonyság tesztelése érdekében.

Továbbá, kutatásunk újszerúségét adta az adatfelvétel eltérő módjából származó összehasonlító elemzés: papír-ceruza alapon és online módon válaszoló vizsgálati személyeket hasonlítottunk össze egymással. Ezáltal két kérdésre kerestük a választ: 1. Mennyire tekinthetók ökológiailag validnak az online térben történő kérdőíves adatfelvétel eredményei idős populáció esetén? 2. Közvetett módon arra is kerestük a választ, hogy az internethasználat jelent-e életminőségbeli előnyt, együtt jár-e magasabb jólléttel és alacsonyabb depresszióval a vizsgált időskori populáció vonatkozásában? A módszertani kérdésre válaszolva megállapítható, hogy az online felületen elérhetó vizsgálati személyek egyes demográfiai jellemzőiket tekintve különböznek a papír alapon válaszoló társaiktól. A kérdoóivet online módon kitöltő vizsgálati személyek fiatalabbak és iskolázottabbak papír-ceruza alapon válaszoló társaiknál. Ha azonban a nem, az életkor és az iskolázottság változóját kontroll alatt tartjuk, akkor nem mutatkozik szignifikáns különbség a két csoport között sem az életminőség, sem a jóllét, sem pedig a depresszió tekintetében. Következésképpen megállapítható, hogy az életminőség, a jóllét és a depresszió vonatkozásában az online térben gyújtött adatok ökológiailag validak, azaz az online térben gyújtött adatok érvényesek, nem torzítják a korábban levont következtetéseket. Mindemellett megállapíthatjuk, hogy az internethasználattal összefüggésbe hozható pszichológiai változók (pl. társas támogatás, kognitív funkciók - lásd 2. alfejezet) empirikus vizsgálata megköveteli a módszertani alaposságot, kiváltképp a nem, az életkor és az iskolázottság kontroll alatt tartását.

Második kérdésünk közvetett módon az internethasználat protektív szerepét járta körül. Eredményeink szerint az életkor és az iskolai végzettség kontrollálása mellett nem jelentkezik szignifikáns életminőségbeli, jóllétbeli különbség vagy alacsonyabb depresszió pontszám az online felhasználók javára. Ezt igazolja az is, hogy a két csoportban nem találtunk szignifikáns különbséget a depresszió előfordulási gyakoriságában, egyik, általunk használt mérőeszköz alkalmazásával sem. 


\section{Korlátok}

Eredményeink értelmezésénél figyelembe kell venni jelen tanulmány korlátait is, amelynek sorában legmeghatározóbb a mintagyújtés nem valószínúségi, kényelmi jellege. Ez a közölt eredmények széles körú általánosíthatóságát jelentősen korlátozza, kiváltképp a depresszió előfordulási gyakoriságának vonatkozásában. Keresztmetszeti kutatásról lévén szó, az eredmények nem teszik lehetővé a prediktív validitás ellenőrzését, illetve az ismételt méréses megbízhatóságot sem teszteltük. Fontos továbbá kiemelnünk, hogy jelen vizsgálat esetén a női nem túlsúlya is megjelent. Szintén korlátot jelent, hogy az adatfelvétel során nem gyújtöttünk adatokat az idősek krónikus betegségeiról vagy aktuális szomatikus tüneteiről, gyógyszerszedésükről, amelyek akár közvetlenül vagy közvetve hatnak a depresszió kialakulására, mintegy látens változóként. Gondolunk itt például a pajzsmirigy alulmúködésre, szívkoszorúér-betegségre, miokardiális infarktusra, a diabéteszre, vagy a központi idegrendszer betegségeire, amelyek a depresszióra hajlamosító tényezőként hatnak (pl. Parkinson-kór, Alzheimer-kór, sclerosis multiplex, stroke). Továbbá, számos időskorban alkalmazott gyógyszer mellékhatásaként (pl. béta-blokkolók, szteroidok, antiepileptikumok, kálciumcsatorna-blokkolók) jelentkezhet depresszió (Rihmer \& Gonda, 2011). Végül, hangsúlyozandó, hogy a tanulmány elsődleges célja a Rövid Geriátriai Depresszió Skála pszichometriai jellemzőinek közreadása volt, így nem korrigáltunk olyan változókra, mint például a betegek mentális állapota. Ez utóbbi a későbbiekben nem hagyható figyelmen kívül, hiszen a depresszió mellett a modern klasszifikációs rendszerek számos olyan neurokognitív zavart azonosítanak, amelyek tovább árnyalhatják az idősek állapotát. Ugyanakkor a mentális állapot vonatkozásában szintén hangsúlyozandó, hogy az etiológia alapján beszélünk primer és szekunder major neurokognitív zavarról, valamint ezek reverzibilis és irreverzibilis formájáról egyaránt. A reverzibilis típusok esetében kiemelten fontos a körültekintő differenciáldiagnosztika, kiváltképp a depresszió vizsgálata, amely azonban már a következő, klinikai mintán történő kutatásunk célkitúzéséhez tartozik. Mindemellett, a klinikai mintán történő folytatáshoz hozzátartozik a szenzitivitás és specificitás meghatározásának kérdésköre, amely a ROC-görbe alkalmazásával válik lehetővé, hiszen ennek elemzése mutatja meg, hogy egy adott kérdőív - jelen esetben a Rövid Geriátriai Depresszió Skála - mennyire tudja elkülöníteni a betegségben szenvedóket, a betegségben nem szenvedőktől. Végül, a valószínúségi tesztelméleten alapuló (IRT) modellezés is indokolt lenne, amely lehetővé teszi a kérdőív tételeinek és a tesztet kitöltők sajátosságainak egyidejú megragadását. 


\section{Irodalom}

Ajtay, G., Petruska, É., Hegyi, N., \& Perczel Forintos, D. (2008). A háziorvosi szolgálatban megforduló személyek reménytelenségének vizsgálata. Psychiatria Hungarica, 23, 34-42.

Alexopoulos, G. S. (2005). Depression in the elderly. Lancet, 365, 1961-1970.

Allaire, J. C., Mclaughlin, A. C., Trujillo, A., Whitlock, L. A., Laporte, L., \& Gandy, M. (2013). Successful aging through digital games: socioemotional differences between older adult gamers and Non-gamers. Computers in Human Behavior, 29, 1302-1306.

Anguera, J. A., Gunning, F. M., \& Areán, P. A. (2017). Improving late life depression and cognitive control through the use of therapeutic video game technology: A proof-ofconcept randomized trial. Depression and Anxiety, 34(6), 508-517.

Apóstolo, J. L., Loureiro, L. M., Reis, I. A., Silva, I. A., Cardoso, D. F., \& Sfetcu, R. (2014). Contribuição para a adaptação da geriatric depression scale-15 para a língua portuguesa. Revista de Enfermagem Referência, 20, 65-73.

Bae, J. N., \& Cho, M. J. (2004). Development of the Korean version of the Geriatric Depression Scale and its short form among elderly psychiatric patients. Journal of Psychosomatic Research, 57, 297-305.

Bech, P., Staehr-Johansen, K., \& Gudex, C. (1996). The WHO (Ten) Well-Being Index: validation in diabetes. Psychotherapy and Psychosomatics, 65, 183-190.

Beck, A. T., Ward, C. H., \& Mendelson, M. (1961). An inventory for measuring depression. Archives of General Psychiatry, 4, 561-571.

Bouvard, M., Charles, S., Guerin, J., Aimard, J., \& Cottraux, J. (1992). Study of the Hopelessness Scale: validation and factorial analysis. L'encephale, 18, 237-240.

Brown, P. J., Woods, C. M., \& Storandt, M. (2007). Model stability of the 15-item Geriatric Depression Scale across cognitive impairment and severe depression. Psychology and Aging, 22, 372-379.

Caprara, G. V., Barbaranelli, C., Borgogni, L., \& Perugini, M. (1993). The “Big Five Questionnaire": A new questionnaire to assess the five factor model. Personality and Individual Differences, 15, 281-288.

Chou, C., \& Bentler, P. M. (1995). Estimates and tests in structural equation modeling. In R. H. Hoyle (Ed.), Structural equation modeling: Concepts, issues, and applications (37-55). Thousand Oaks, CA: Sage

Cohen, J. (1988). Statistical power analysis for the behavioral sciences ( $2^{\text {nd }}$ ed.). Lawrence Erlbaum: New Jersey

Cotten, S. R., Anderson, W. A., \& McCullough, B. M. (2013). Impact of internet use on loneliness and contact with others among older adults: cross-sectional analysis. Journal of Medical Internet Research, 15(2), 215-227.

Cotten, S. R., Ford, G., \& Hale, T. M. (2014). Internet use and depression among retired older adults in the United States: A longitudinal analysis. The Journal of Gerontology, 69, 763-771.

Cotten, S. R., Ford, G., Ford, S., \& Hale, T. M. (2012). Internet use and depression among older adults. Computers in Human Behavior, 28, 496-499.

Cramér, H. (1946). Mathematical methods of statistics. Princeton: Princeton University Press

Curran, P. J., West, S. G., \& Finch, J. F. (1996). The robustness of test statistics to nonnormality and specification error in confirmatory factor analysis. Psychological Methods, 1, 16-29.

Drasgow, F., \& Parsons, C. K. (1983). Application of unidimensional item response theory models to multidimensional data. Applied Psychological Measurement, 7, 189-199.

European Commission (2017). The 2018 Ageing Report. Underlying Assumptions \& Projection Methodologies. Institutional Paper, 65, 1-260. 
Eurostat (2018). Eurostat's survey on ICT usage in households and by individuals. Letöltve: 2020.04.08-án: http:// appsso.eurostat.ec.europa.eu/nui/show.do?dataset=isoc_ci_ ac_i\&lang=en

Ferrando, P. J., \& Lorenzo-Seva, U. (2018). Assessing the quality and appropriateness of factor solutions and factor score estimates in exploratory item factor analysis. Educational and Psychological Measurement, 78, 762-780.

Field, A. (2005). Discovering statistics using SPSS (2nd ed.). London: Sage Publications, Inc.

Forlani, C., Morri, M., Ferrari, B., Dalmonte, E., Menchetti, M., De Ronchi, D., \& Atti, A. R. (2014). Prevalence and gender differences in late-life depression: A population-based study. American Journal of Geriatric Psychiatry, 22, 370-380.

Friedman, B., Heisel, M. J., \& Delavan, R. L. (2005). Psychometric properties of the 15-item Geriatric Depression Scale in functionally impaired, cognitively intact, communitydwelling elderly primary care patients. Journal of American Geriatric Society, 53, 1570-1576.

Gallo, J., \& Bogner, H. (2003). Nemzetközi adatok. In: M. Kovács (szerk.). Időskori depresszió és szorongás. Budapest: Springer Tudományos Kiadó, 38-43.

Gautam, R., \& Houde, S. (2011). Geriatric Depression Scale for community-dwelling older adults in Nepal. Asian Journal of Gerontology \& Geriatrics, 6, 93-99.

Girgus, J. S., Yang, K., \& Ferri, C. V. (2017). The gender difference in depression: are elderly women at greater risk for depression than elderly men? Geriatrics, 2, 35, 1-21.

Gonda, X., Molnár, E., Torzsa, P., \& Rihmer, Z. (2009). Az időskori depresszió differenciáldiagnosztikája. Háziorvosi Továbbképző Szemle, 14, 53-60.

Granello, D. H., \& Wheaton, J. E. (2004). Online data collection: Strategies for research. Journal of Counseling and Development, 82(4), 387-393.

Greenberg, S. A. (2012). The Geriatric Depression Scale (GDS). Best Practices in Nursing Care to Older Adults, 4(1), 1-2. Letöltve: 2021. 05. 11-én: https:/ / wwwoundcare.ca/Uploads/ ContentDocuments/Geriatric\%20Depression\%20Scale.pdf

Horn, J. L. (1965). A rationale and test for the number of factors in factor analysis. Psychometrika, 30(2), 179-185.

IBM Corp. (2013). IBM SPSS Statistics for Windows, Version 22.0. Armonk, NY: IBM Corp.

Imai, H., Yamanaka, G., Ishimoto, Y., Kimura, Y., Fukutomi, E., Chen, W., et al. (2014). Factor structures of a Japanese version of the Geriatric Depression Scale and its correlation with the quality of life and functional ability. Psychiatry Research, 215, 460-465.

Incalzi, R. A., Cesari, M., Pedone, C., \& Carbonin, P. U. (2003). Construct validity of the 15-item Geriatric Depression Scale in older medical inpatients. Journal of Geriatric Psychiatry Neurology, 16, 23-28.

Jang, Y., Small, B. J., \& Haley, W. E. (2010). Cross-cultural comparability of the Geriatric Depression Scale: comparisons between older Koreans and older Americans. Aging and Mental Health, 5, 31-37.

Kamalpour, M., Watson, J., \& Buys, L. (2020). How can online communities support resilience factors among older adults. International Journal of Human-Computer Interaction, 36, 1342-1353.

Khosravi, P., Rezvani, A., \& Wiewiora, A. (2016). The impact of technology on older adults' social isolation. Computers in Human Behavior, 63, 594-603.

Kim G., DeCoster J., Huang C. H., \& Bryant, A. N. (2013). A meta-analysis of the factor structure of the geriatric depression scale (GDS): The effects of language. International Psychogeriatric, 25, 71-81.

Kósa, K., \& Bíró, É. (2018). A mentális állapot populációs szintú vizsgálatának koncepciói és eszközei. Mentálhiginé és Pszichoszomomatika, 19, 103-139. 
Kovács, M., Kopp, M., \& Rózsa, S. (2003). Hazai adatok. In: M. Kovács (szerk.). Időskori depresszió és szorongás. Budapest: Springer Tudományos Kiadó, 44-54.

Kovács, K., \& Tóth, G. (2015). Egészségi állapot. In: J. Monostori, P. Öri, \& Zs. Spéder (szerk.), Demográfiai portré 2015: Jelentés a magyar népesség helyzetéről (95-114). Budapest: KSH Népességtudományi Kutatóintézet

Kühn, S., Berna, F., Lüdtke, T., Gallinat, J., \& Moritz, S. (2018). Fighting Depression: Action Video Game Play May Reduce Rumination and Increase Subjective and Objective Cognition in Depressed Patients. Frontiers in Psychology, 9. DOI: 10.3389/fpsyg.2018.00129

Kühn, S., \& Gallinat, J. (2013). Amount of lifetime video gaming is positively associated with entorhinal, hippocampal and occipital volume. Molecular Psychiatry, 19(7), 842-847.

Lai, D., Tong, H., Zeng, Q., \& Xu, W. (2010). The factor structure of a Chinese Geriatric Depression Scale-SF: use with alone elderly Chinese in Shanghai, China. International Journal of Geriatric Psychiatry, 25, 503-510.

Lee, J., Park, H., \& Chey, J. (2018). Education as a protective factor moderating the effect of depression on memory impairment in elderly women. Psychiatry Investigation, 15, 70-77.

Lee, S. H., \& Kim, Y. B. (2014). Which type of social activities decrease depression in the elderly? An analysis of a population-based study in South Korea. Iranian Journal of Public Health, 43, 903-912.

Levy, M. J. F., Boulle, F., Steinbusch, H. W., van den Hove, D. L. A., Kenis, G., \& Lanfumey, L. (2018). Neurotrophic factors and neuroplasticity pathways in the pathophysiology and treatment of depression. Psychopharmacology, 235(8), 2195-2220.

Liao, S., Zhou, Y., Liu, Y., \& Wang, R. (2020). Variety, frequency, and type of Internet use and its association with risk of depression in middle- and older-aged Chinese: a crosssectional study. Journal of Affective Disorders, 273, 280-290.

Lichtenberg, P. A. (Ed.) (2010). Handbook of Assessment in Clinical Gerontology. $2^{\text {nd }}$ ed. Burlington: Elsevier, Inc.

Liu, Y., Wang, Z., \& Xiao, W. (2017). Risk factors for mortality in elderly patients with hip fractures: a meta-analysis of 18 studies. Aging Clinical and Experimental Research, 30, 323-330.

Lorenzo-Seva, U., \& Ferrando, P. J. (2006). FACTOR: A computer program to fit the exploratory factor analysis model. Behavior Research Methods, 38, 88-91.

Lorenzo-Seva, U., \& Ferrando, P. J. (2013). FACTOR 9.2 A comprehensive program for fitting exploratory and semiconfirmatory factor analysis and IRT models. Applied Psychological Measurement, 37, 497-498.

Mackichan, F., Adamson, J., \& Gooberman-Hill, R. (2013). “Living within your limits": activity restriction in older people experiencing chronic pain. Age and Ageing, 42(6), 702-708.

McGuire, L., Ford, E., \& Umed, A. (2006). Cognitive functioning as a predictor of functional disability in later life. American Journal of Geriatric Psychiatry, 14, 36-42.

Mészáros, G., \& Szikriszt, É. (2013). A Geriátriai depressziós skála beválásának gyakorlati tapasztalatai. Orvosi Rehabilitáció és Fizikális Medicina Magyarországi Társasága XXXII. Vándorgyúlése, Miskolc, 2013. augusztus 29-31. Rehabilitáció, 23(3), 134-135. Letöltve: 2019. 08. 02-án: http://www.kmcongress.com/eloadasok/rehab2013/meszaros_ gabriella.pdf

Monostori, J., \& Gresits, G. (2018). Idősödés. In: J. Monostori, P. Őri, \& Zs. Spéder (szerk.). Demográfiai portré 2018: Jelentés a magyar népesség helyzetéről. Budapest: KSH Népességtudományi Kutatóintézet, 127-145.

Morizot, J., Ainsworth, A. T., \& Reise, S. P. (2009). Toward modern psychometrics: application of item response theory models in personality research. In: R. W. Robins, R. C. Fraley, \& R. F. Krueger (Eds.). Handbook of Research Methods in Personality Psychology. New York: Guilford Press, 407-421. 
Muthén, B. O., \& Kaplan, D. (1985). A comparison of some methodologies for the factor analysis of nonnormal Likert variables. British Journal of Mathematical and Statistical Psychology, 38, 171-189.

Muthén, B. O., \& Kaplan, D. (1992). A comparison of some methodologies for the factor analysis of non-normal Likert variables: A note on the size of the model. British Journal of Mathematical and Statistical Psychology, 45, 19-30.

Nemzeti Média és Hírközlési Hatóság (NMHH) (2018). Lakossági internethasználat. Online piackutatás 2018. Letöltve: 2019. 09. 12-én: https://nmhh.hu/dokumentum/202180/ lakossagi_internethasznalat_2018.pdf

Onishi, J., Suzuki, Y., Umegaki, H., Endo, H., Kawamura, T., \& Iguchi, A. (2006). A comparison of depressive mood of older adults in a community, nursing homes, and a geriatric hospital: factor analysis of Geriatric Depression Scale. Journal of Geriatric Psychiatry and Neurology, 19, 26-31.

Osváth,P.(2013). Azidőskori depresszióés agitáció korszerű kezelése. Neuropsychopharmacologia Hungarica, 15, 147-155.

Paulik, E., Belec, B., Molnár, R., Müller, A., Belicza, É., Kullmann, L., \& Nagymajtényi, L. (2007). Az Egészségügyi Világszervezet rövidített életminőség kérdőívének hazai alkalmazhatóságáról. Orvosi Hetilap, 148, 155-160.

Pachana, N. A., McLaughlin, D., Leung, J., Byrne, G., \& Dobson, A. (2011). Anxiety and depression in adults in their eighties: do gender differences remain? International Psychogeriatrics. 22, 1-6.

Pék, Gy., Égerházi, A., \& Kovács, M. (2003). Pszichológiai tesztek, diagnosztikai kérdőívek, tünetbecslő skálák. In: M. Kovács (szerk.). Időskori depresszió és szorongás (141-157). Budapest: Springer Hungarica

Perczel-Forintos, D., Ajtay, Gy., Barna, Cs., Kiss, Zs., \& Komlósi, S. (2018). Kérdőívek, becslöskálák a klinikai pszichológiában. Budapest: Semmelweis Kiadó

Proyer, R. T., Gander, F., Wellenzohn, S., \& Ruch, W. (2014). Positive psychology interventions in people aged 50-79 years: Long-term effects of placebo-controlled online interventions on well-being and depression. Aging and Mental Health, 18, 997-1005.

Rihmer, Z., \& Gonda, X. (2011). Depresszió időskorban. In: É. Takács (szerk.). Az idősgondozás kézikönyve: Geriátriai szolgáltatók kézikönyve: A magyarországi idősotthonokés hospice-ok adatbázisával (147-158). Budapest: Geriáter Service Kiadó

Rózsa S., Kő N., \& Oláh A. (2006). Rekonstruálható-e a Big Five a hazai mintán. A Caprara-féle "Big Five Kérdőív" (BFQ) felnőtt változatának hazai adaptációja és nemzetközi összehasonlitó elemzése. Budapest: ELTE, Pszichológiai Intézet

Şar, A. H., Göktürkb, G. Y., Turac, G., \& Kazazd, N. (2012). Is the internet use an effective method to cope with elderly loneliness and decrease loneliness symptom? Procedia Social and Behavioral Sciences, 55, 1053-1059.

Sheikh, J. I., \& Yesavage, J. A. (1986). Geriatric Depression Scale (GDS): Recent evidence and development of a shorter version. Clinical Gerontologist: The Journal of Aging and Mental Health, 5, 165-173.

Simon A. (1994). A Zung-féle Önértékelő Depresszió Skála (ÖDS). In: F. Mérei, \& F. Szakács (szerk.). Pszichodiagnosztikai Vademecum, 180-184. Budapest: Nemzeti Tankönyvkiadó

Sims, T., Reed, A. E., \& Carr, D. C. (2017). Information and communication technology use is related to higher well-being among the oldest-old. Journals of Gerontology, Series B: Psychological Sciences and Social Sciences, 72, 761-770.

Small, G. W., Moody, T. D., Siddarth, P., \& Bookheimer, S. Y. (2009). Your brain on google: Patterns of cerebral activation during internet searching. American Journal of Geriatric Psychiatry, 17, 116-126. 
Stolić, D., Jović, J., Bukumirić, Z., Rančić, N., Stolić, M., \& Ignjatović-Ristić, D. (2015). The Serbian version of the geriatric depression scale: reliability, validity and psychometric features among the depressed and non-depressed elderly. Engrami, 37, 51-64.

Susánszky, É., Konkoly Thege, B., Stauder, A., \& Kopp, M. (2006). A WHO Jól-lét kérdőív rövidített (WBI-5) magyar változatának validálása a Hungarostudy 2002 országos lakossági egészségfelmérés alapján. Mentálhigiéné és Pszichoszomatika, 7, 247-255.

Sutin, A. R, Terracciano, A., Milaneschi Y., An, Y., Ferrucci, L., \& Zonderman, A. B. (2012). The trajectory of depressive symptoms across the adult life span. JAMA Psychiatry. 70, 803-811.

Székelyi, M., \& Barna, I. (2002). Túlélőkészlet az SPSS-hez. Többváltozós elemzési technikákról társadalomkutatók számára. Budapest: Typotex Kiadó

Timmerman, M. E., \& Lorenzo-Seva, U. (2011). Dimensionality assessment of ordered polytomous items with parallel analysis. Psychological Methods, 16(2), 209-220.

Torzsa, P., Szeiffert, L., Dunai, K., Kalabay, L., \& Novák, M. (2009). A depresszió diagnosztikája és kezelése a családorvosi gyakorlatban. Orvosi Hetilap, 36, 1684-1693.

Wilcox, R. R. (2010). Fundamentals of modern statistical methods: Substantially improving power and accuracy. New York: Springer

World Health Organization (1996). WHOQOL-BREF: Introduction, Administration, Scoring and Generic Version of the Assessment: Field Trial Version. World Health Organization, Geneva. Letöltve: 2019. 09. 10-én: https://www.who.int/mental_health/media/en/76. pdf

World Health Organization (2008). The Global Burden of Disease: 2004 Update. Geneva, Switzerland: World Health Organization

Wu, W., Gao, X., \& Li, G. (2017). The biological mechanisms of anhedonia in depression. Chinese Journal of Behavioral Medicine and Brain Science, 26(3), 284-288.

Yesavage, J. A., Bring, T. L., Rose T. L., Lum, O., Huang, V., Adey, M., \& Von Leirer, O. (1983). Development and validation of a Geriatric Depression Screening Scale: A preliminary report. Journal of Psychiatry Research, 17, 37-49.

Zhang, M. W. B., Bach Xuan, T., Huong Thi, L., Hinh Duc, N., Cuong Tat, N., Tho Dinh, T., et al. (2017). Perceptions of health-related information on Facebook: Cross-sectional study among Vietnamese youths. Interactive Journal of Medical Research, 6(2), e16. DOI: 10.2196/ijmr.8072

Zhao, H., He, J., Yi, J., \& Yao, S. (2019). Factor structure and measurement invariance across gender groups of the 15-item geriatric depression scale among Chinese elders. Frontiers in Psychology, 10, 1360. DOI: 10.3389/fpsyg.2019.01360

Zung, W. W. (1965). A self-rating depression scale. Archives of General Psychiatry, 12, 63-70.

\section{Köszönetnyilvánítás}

Ezúton mondunk köszönetet az ÚNKP ösztöndíj anyagi támogatásáért, a vizsgálatban részt vevő időseknek és idősek otthonának az együttmúködésért. Dr. Gonda Xéniának és Dr. Tölgyes Tamásnak köszönjük a kézirathoz fúzött hasznos tanácsait. A kézirat ismeretlen lektorainak és felelős szerkesztőjének értékes javaslataikért és gondos munkájukért szintén köszönetünket fejezzük ki. 


\title{
Anyagi támogatás
}

A közlemény megírása, illetve a kapcsolódó kutatómunka anyagi támogatásban részesült az Új Nemzeti Tehetség Program ÚNKP-18-2-I-PPKE-83 számú pályázata által.

\section{Szerzői munkamegosztás}

Szekeres Tamás: a kutatási módszertan kidolgozása, a vizsgálat lefolytatása, szakirodalomkutatás, statisztikai elemzések, a kézirat első változatának kialakítása és megszövegezése. Hargitai Rita: a kutatási módszertan kidolgozása és szupervíziója, a statisztikai adatok értelmezése, a kézirat véglegesítése. A cikk végleges változatát mindkét szerző elolvasta és jóváhagyta.

\section{Nyilatkozat érdekütközésról}

A szerzók ezúton kijelentik, hogy esetükben nem állnak fenn érdekütközések.

\section{Experiences with the usage of the 15-item Geriatric Depression Scale (Short Form) on a Hungarian sample}

\author{
SZEKERES, TAMÁS - HARGITAI, RITA
}

Introduction: Geriatric depression is the leading mental disorder among the older population, although it is often underdiagnosed. The Geriatric Depression Scale (Short Form) (GDS-SF) is a screening tool designed to measure depressive symptoms in older adults and is used by clinicians globally. Objective: The primary objective of the study is the psychometric testing of GDS-SF among pensioners, as well as to present our experiences with using the questionnaire on a Hungarian sample. The secondary objective of the study is to explore whether the use of online space is a protective factor against developing depressive symptoms in this population. Methods: A total of 309 participants took part in this cross-sectional study, all of them above the age of 65 , with full anonymity granted to all involved. The questionnaire was available in paper-based $(n=142)$ and online $(n=167)$ format as well. For the validation of GDS-SF, the Abbreviated World Health Organization Quality of Life Questionnaire, the Abbreviated WHO Well-Being Questionnaire, and the Zung Self-Rating Depression Scale were used. The Social Desirability Scale of the Caprara Big Five Questionnaire was used to filter out response distortion tendencies. Results: The results of the parallel analysis of the questionnaire supported a one-factor structure design, with $64.8 \%$ of the variance explained. According to the validity analysis, GDS-SF showed sufficient direction and degree of correlation with the questionnaires used for comparison and was in accordance with our a priori assumed direction and degree of correlation. Upon examination we discovered that the GDF-SF has a correlation coefficient $(r)$ between -0.59 and $-0.61(p<0.001)$ with the quality of life subfactors, $-0.71(p<0.001)$ with wellbeing, and $0.74(p<0.001)$ with Zung Self-Rating Depression Scale. The reliability of the survey also proved to be excellent. There was no significant difference between the prevalence of 
depression between the two groups (paper-based and online), when controlling for the effects of age and level of education. Conclusions: The Hungarian version of the 15-item Geriatric Depression Scale is a reliable and valid tool for measuring depressive symptoms in the older normative adult population. Regarding the clinical sample, further exploration is needed.

Keywords: depression in older adults, Geriatric Depression Scale (Short Form), psychometric properties, online data collection

A cikk a Creative Commons Attribution 4.0 International License (https:/ / creativecommons.org/ licenses/by/4.0/) feltételei szerint publikált Open Access közlemény, melynek szellemében a cikk bármilyen médiumban szabadon felhasználható, megosztható és újraközölhetó, feltéve, hogy az eredeti szerző és a közlés helye, illetve a CC License linkje és az esetlegesen végrehajtott módosítások feltüntetésre kerülnek. (SID_1) 